\title{
Pattern of Metastases of Squamous Cell Carcinoma in Cervical Lymph Node In Patients With Occult Primary
}

Kishore Kumar Halder ${ }^{1 *}$, Md. Shafiullah², Md. Saiful Islam¹, ABM Lutful Kabir ${ }^{1}$, Banani Rani Mondal ${ }^{3}$, Mahbubul Alam Choudhury $^{4}$, Md. Feroz Hossen ${ }^{5}$

Assistant Professor, Department of ENT, Abdul Malek Ukil Medical College, Noakhali, Bangladesh
${ }^{2}$ Associate Professor, Department of ENT, Abdul Malek Ukil Medical College, Noakhali, Bangladesh
${ }^{3}$ Lecturer, Department of Forensic Medicine, Abdul Malek Ukil Medical College, Noakhali, Bangladesh
${ }^{4}$ Assistant Professor, ENT Department, Nilphamary Medical College, Nilphamary, Bangladesh
${ }^{5}$ Assistant Professor \& Head of Department (ENT), Northern Private Medical College, Rangpur, Bangladesh

Article History
Received: 02.12 .2021
Accepted: 05.01 .2022
Published: 10.01 .2022
Journal homepage:
https://www.easpublisher.com
Quick Response Code

Abstract: Introduction: Squamous cell carcinoma is the most common cancer of the upper aerodigestive tract, accounting for more than $90 \%$ of cancers. Its method of spread is through lymphatic channels, with a high propensity toward deposition in the regional lymph nodes. Objective: To determine the pattern of metastesis of squamous cell carcinoma in cervical lymph node in patients with occult primary. Methods: This was an observational cross sectional study which was carried out in the Dept. of ENT, Abdul Malek Ukil Medical College Hospital, Noakhali, Bangladesh from January 2017 to June2019. A Total 31 patients were selected according to selection criteria and level of involved lymph node and nodal staging was determined by careful clinical examination, biopsy of all suspicious site, CT scan, MRI, USG and X-ray. Results: Thirty One patients with metastatic neck node in whom the primary tumour was not found despite of extensive diagnostic procedure were studied in this series. Patients distribution Male were $78 \%$ and female $22 \%$. In this study majority of patients were within 40-80 years and most of patients were male. Unilateral neck node metastasis was found in $90.32 \%$ cases and bilateral in $09.68 \%$ cases. There is high incidence of unilateral metastatic neck node. Involved lymph node was found single in $54.83 \%$ and multiple in $45.17 \%$ cases in our study. Consistency of lymph nodes were found hard in $51.61 \%$, firm to hard in $32.25 \%$ and firm in $16.12 \%$ cases in our study. In this study nodes were found less than $3 \mathrm{~cm}$ in $38.70 \%$ cases, $3-6 \mathrm{~cm}$ in $48.38 \%$ cases and more than 6 $\mathrm{cm}$ in $12.90 \%$ cases. While levelling of the lymph node was concerned, in this study the most commonly involved lymph node region was level-II (41.93\%) followed by level-III $(16.12 \%)$. In this study $38.70 \%$ cases were in stage $\mathrm{N}_{1}$, $48.38 \%$ in stage $\mathrm{N}_{2}$ and $12.90 \%$ in stage $\mathrm{N}_{3}$. Maximum lymph nodes were 3-6 $\mathrm{cm}$ in size. Conclusion: Metastetic squamous cell carcinoma in cervical lymph node of occult primary common in elderly patient and most of were male and involved the lymph node level II.

Keywords: Squamous cell carcinoma, metastasis, occult primary, cervical lymph node.

Copyright (C) 2022 The Author(s): This is an open-access article distributed under the terms of the Creative Commons Attribution 4.0 International License (CC BY-NC 4.0) which permits unrestricted use, distribution, and reproduction in any medium for non-commercial use provided the original author and source are credited.

\section{INTRODUCTION}

Squamous cell carcinoma is the most common cancer of the upper aerodigestive tract, accounting for more than $90 \%$ of cancers. Its method of spread is through lymphatic channels, with a high propensity toward deposition in the regional lymph nodes. It is well known that the presence of cervical lymph node metastasis is the most important prognostic indicator, with a $50 \%$ reduction in 5-year survival compared to those without neck metastasis. Despite many common features, squamous cell carcinomas of the head and neck vary in their metastatic potential. Squamous cell carcinoma is the most common malignant tumor in the head and neck region [1]. Lymphatic spread is the most important mechanism in the spread of the head and neck squamous cell carcinomas [2]. The rate of 
metastases to cervical lymph nodes probably reflects the aggressiveness of the primary tumor. The presence of metastases in a lymph node is said to reduce the 5year survival rate by about $50 \%$ [3]. Carcinoma of unknown primary site represent a heterogenous group of malignancies presenting with lymph node and only $2-3 \%$ of patients with head \& neck malignancy [4,5]. Carcinoma of unknown primary is about $5-10 \%$ of all tumours. Now a-days FDG-PET and FDG-CT has introduced [4]. The term carcinoma of unknown primary origin should be used if no evidence of primary tumour is found after adequate clinical examination, fibreoptic endoscopy and conventional radiological investigations. Metastasis most commonly developed at nodal levels II and III with less frequent involvement of level I, IV, V and VI. Squamous cell carcinoma is the most common histiotypes in case of unknown primary. Diagnostic procedures of carcinoma of unknown primary include a full ENT examination with nasoendoscopic examination of upper aero-digestive tract, CT scan and MRI. The majority of these patients will have an occult squamous cell carcinoma of the upper aerodigestive tract, although infrequently other histological types and primary sites do occur [5]. These conventional process of clinical examination, panendoscopy, CT and/or MRI followed by panendoscopy with biopsy have been shown to reveal the primary site in over $40 \%$ of patients initially diagnosed with neck node metastasis squamous cell carcinoma of unknown primary origin [6]. Cervical lymph node metastasis in occult primary may present as the first and only symptom. So it is essential to know the level of involvement, number of nodes, size of nodes and fixity of nodes in order to identify the primary site as well as staging of the disease which will help to assess the prognosis of the disease.

\section{Materials AND Methods}

This was an observational cross sectional study which was carried out in the Dept. of ENT, Abdul Malek Ukil Medical College Hospital, Noakhali, Bangladesh from January 2017 to June-2019. Sample size 31 patients. Patient of cervical lymph node metastasis with squamous cell carcinoma in occult primary.

\section{Inclusion Criteria}

- The male and female patient of cervical lymph node metastasis of squamous cell carcinoma with occult primary.

\section{Exclusion Criteria}

- Metastatic neck mass other than squamous cell carcinoma.

\section{Data Collection \& Analysis}

Purposive sampling technique was adopted. All the available subjects during the data collection period who fulfilled the study selection criteria were included in the study. Complete history taking and clinical examination were done and recorded in data collection sheet. After collection all the data were checked and edited. Then data were entered into computer with the help of software SPSS 20 version.

\section{ReSUlts}

Thirty One patients with metastatic neck node in whom the primary tumour was not found despite of extensive diagnostic procedure were studied in this series. Male female ratio was found 3.5:1 which is consistent with other relevant studies. Male were $78 \%$ and female $22 \%$ (Table-1, Fig-1).

Table-1: Distribution of Age group $(n=31)$

\begin{tabular}{|l|l|l|}
\hline Age group (Years) & Number of cases & Percentage (\%) \\
\hline $20-30$ & Nil & 0 \\
\hline $31-40$ & 1 & 3.22 \\
\hline $41-50$ & 6 & 19.35 \\
\hline $51-60$ & 16 & 51.61 \\
\hline $61-70$ & 6 & 19.35 \\
\hline $71-80$ & 2 & 6.46 \\
\hline \multicolumn{2}{|c|}{ Most of patient belonged to age 51-60 years. }
\end{tabular}

Most of patient belonged to age 51-60 years.

The male to female ratio was $3.5: 1$

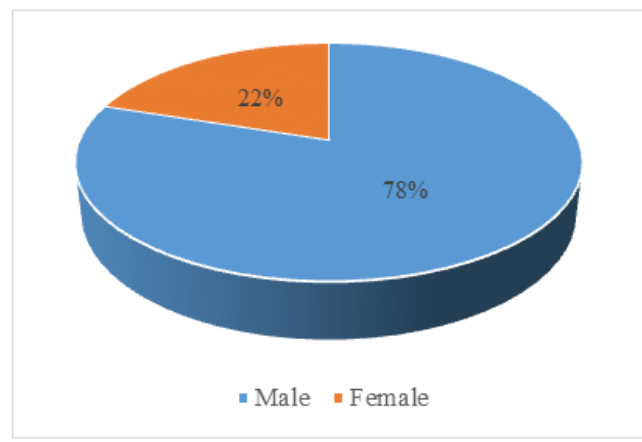

Fig 1: Sex distribution 
Table-2: Distribution and status of involved lymph node

\begin{tabular}{|l|l|l|}
\hline Distribution of nodes & Number of cases & Percentage \\
\hline Unilateral & 28 & 90.32 \\
\hline Bilateral & 03 & 09.68 \\
\hline No. of node involvement & 17 & 54.83 \\
\hline Single & 14 & 45.17 \\
\hline Multiple & \multicolumn{2}{|l|}{} \\
\hline Consistency & 16 & 51.61 \\
\hline Hard & 10 & 32.25 \\
\hline Firm to Hard & 05 & 16.12 \\
\hline Firm & 19 & 61.29 \\
\hline Mobility & 12 & 38.71 \\
\hline Mobile & 12 & 38.70 \\
\hline Fixed & 15 & 48.38 \\
\hline Mobility & 1 & 12.90 \\
\hline$<3 \mathrm{~cm}$ & 4 & \\
\hline $3-6 \mathrm{~cm}$ &
\end{tabular}

Involved lymph node was found single in $53.33 \%$ and multiple in $46.66 \%$ cases in our study. Single and multiple lymph node enlargement were found in $61.3 \%$ and $38.7 \%$ respectively in one study. In this study nodes were found less than $3 \mathrm{~cm}$ in $38.70 \%$ cases, $3-6 \mathrm{~cm}$ in $48.38 \%$ cases and more than $6 \mathrm{~cm}$ in $12.90 \%$ cases (Table-2).

Table-3: Level of involved lymph node in unknown primary cases $(n=31)$

\begin{tabular}{|l|l|l|}
\hline Level of nodes & Number of cases & Percentage \\
\hline Level- I & 02 & 06.45 \\
\hline Level- II & 13 & 41.93 \\
\hline Level- II+III & 03 & 09.67 \\
\hline Level- III & 05 & 16.12 \\
\hline Level- III+IV & 02 & 06.45 \\
\hline Level- IV & 02 & 06.45 \\
\hline Level- IV+V & 01 & 03.25 \\
\hline Level- V & 03 & 09.67 \\
\hline
\end{tabular}

Highest involvement in Level-II and Level-III

In this study the most commonly involved lymph node region was level-II (50\%) followed by level-III (36.66\%) (Table$3)$.

Table-4: Staging of Lymph node in unknown Primary $(n=31)$

\begin{tabular}{|l|l|l|}
\hline Stage & Number of cases & Percentage \\
\hline Stage $-\mathrm{N}_{1}$ & 12 & 38.70 \\
\hline Stage $-\mathrm{N}_{2}$ & 15 & 48.38 \\
\hline Stage $-\mathrm{N}_{3}$ & 04 & 12.90 \\
\hline
\end{tabular}

Highest presentation in $\mathrm{N} 2$ stage.

In this study $40 \%$ cases were in stage $\mathrm{N}_{1}, 43.66 \%$ in stage $\mathrm{N}_{2}$ and $13.33 \%$ in stage $\mathrm{N}_{3}$ (Table-4).

\section{DiscuSSION}

Lymphatic spread is the most important mechanism in the spread of head and neck squamous cell carcinomas. The rate of metastases probably reflects the aggressiveness of the primary tumor, and is an important prognostic factor [3]. Patients with cervical lymph node metastasis from unknown primary tumour present both diagnostic and therapeutic problems. It is difficult to find out pattern of metastasis in neck of squamous cell carcinoma of unknown origin as only a few studies are available in our country. Thirty One patients with metastatic neck node in whom the primary tumour was not found despite of extensive diagnostic procedure were studied in this series. Thirty One patients with metastatic neck node in whom the primary tumour was not found despite of extensive diagnostic procedure were studied in this series. Patients distribution Male were $78 \%$ and female $22 \%$ which is consistent with other relevant studies [7, 8]. Age of majority of patients $(90 \%)$ were in fifth to seventh decade that are similar to different studies carried out in India [9]. Unilateral neck node metastasis was found in $90.32 \%$ cases and bilateral in $09.68 \%$ cases. There is high incidence of unilateral metastatic neck node $[10,11]$. G.B Snow et al found $88 \%$ 
ipsilateral and $12 \%$ bilateral metastatic neck node which is consistent with this study [12]. Involved lymph node was found single in $54.83 \%$ and multiple in $45.17 \%$ cases in our study. Single and multiple lymph node enlargement were found in $61.3 \%$ and $38.7 \%$ respectively in one study [12]. Another study revealed solitary involvement in $52.4 \%-62.6 \%$ and multiple in $37.5 \%-47.6 \%$ cases [4]. Consistency of lymph nodes were found hard in $51.61 \%$, firm to hard in $32.25 \%$ and firm in $16.12 \%$ cases in our study which is more or less similar to another study where hard in $55 \%$, firm to hard in $40 \%$ and firm in $5 \%$ cases [12]. In this study nodes were found less than $3 \mathrm{~cm}$ in $38.70 \%$ cases, 3-6 $\mathrm{cm}$ in $48.38 \%$ cases and more than $6 \mathrm{~cm}$ in $12.90 \%$ cases. G.B Snow et al showed $<3 \mathrm{~cm}$ in $85 \%$ cases and $>3 \mathrm{~cm}$ in $15 \%$ cases only [12]. This indicates more late presentation of patients in our country which corresponds with ignorance, illiteracy and poor socioeconomic status of our people. In $61.29 \%$ cases lymph nodes were found mobile and $38.71 \%$ cases were found fixed. Mobility of nodes varied $57 \%$ to $60 \%$ and fixed $40 \%$ to $43 \%$ in studies carried out in Bangladesh [10, 11]. While levelling of the lymph node was concerned, in this study the most commonly involved lymph node region was level-II (41.93\%) followed by level-III $(16.12 \%)$. This is with agreement with most other studies demonstrating that the upper jugular lymph node chain is most commonly involved with head and neck nodal metastasis $[2,5,13]$. In this study $38.70 \%$ cases were in stage $\mathrm{N}_{1}, 48.38 \%$ in stage $\mathrm{N}_{2}$ and $12.90 \%$ in stage $\mathrm{N}_{3}$. The higher incidence of $\mathrm{N}_{2}$ stage of lymph node in our series is well reported by other Bangladeshi series $[5,13]$.

\section{Conclusion}

This study was undertaken to assess the pattern of metastasis of squamous cell carcinoma of occult primary in cervical lymph node. It can be concluded that metastatic carcinoma in cervical lymph node is more common in elderly patient and majority of cases are involve level-II cervical lymph node.

\section{REFERENCES}

1. Armstrong, W. B., Vokes, D. E., \& Masel, R. H. (2010). Malignant tumors of the larynx. In: Flint, P. W. (eds) Cummings otolaryngology: head \& neck surgery, 5th edn. Mosby Elsevier, Philadephia.
2. Calabrese, L., Jereczek-Fossa, B. A., Jassem, J., Rocca, A., Bruschini, R., Orecchia, R., \& Chiesa, F. (2005). Diagnosis and management of neck metastases from an unknown primary. Acta otorhinolaryngologica italica, 25(1), 2-12.

3. Rothenberg, S. M., \& Ellisen, L. W. (2012). The molecular pathogenesis of head and neck squamous cell carcinoma. The Journal of clinical investigation, 122(6), 1951-1957.

4. Byers, R. M., Weber, R. S., Andrews, T., McGill, D., Kare, R., \& Wolf, P. (1997). Frequency and therapeutic implications of "skip metastases" in the neck from squamous carcinoma of the oral tongue. Head \& neck, 19(1), 14-19.

5. Dias, F. L., Lima, R. A., Kligerman, J., Farias, T. P., Soares, J. R. N., Manfro, G., \& Sa, G. M. (2006). Relevance of skip metastases for squamous cell carcinoma of the oral tongue and the floor of the mouth. Otolaryngology-Head and Neck Surgery, 134(3), 460-465.

6. Lawrence, E., \& Banister, H. (1995). Lymphatic drainage of Head \& Neck. In Gray's Anatomy, $10^{\text {th }}$ edition, ELBS, Churchill Livingstone, 1611-1613.

7. Quadir, M. A. (1997). A study of incidence, evaluation and management of the occult primary. (Thesis), 90-91.

8. Afroz, M., Akhtar, N., \& Siddiquee, B. H. (2009). Metastatic neck node-a clinical study of 60 cases. Bangladesh Journal of Otorhinolaryngology, 15(1), 26-30.

9. Shukla, P., Gupta, D., Bisht, S. S., Pant, M. C., Bhatt, M. L., Srivastava, K., \& Negi, M. P. S. (2009). Metastatic squamous cell carcinoma neck with occult primary: A retrospective analysis. Indian journal of medical and paediatric oncology: official journal of Indian Society of Medical \& Paediatric Oncology, 30(4), 124-130.

10. Chowdhury, R. K. D. (1987). Cervical lymphadenopathy- A clinicopathological study of 80 cases (Dissertation BCPS).

11. Hossain, I. A. H. (2000). Cervical lymphadenopathy-A clinicopathological study of 100 cases (Dissertation BCPS).

12. Ali, S., Tiwari, R. M., \& Snow, G. B. (1985). False-positive and false-negative neck nodes. Head \& neck surgery, 8(2), 78-82.

13. Ahmad, S. M. U., Huq, A. Z., Joarder, M. A. H., Ahmed, A., \& Rahman, H. (2008). Study on nodal metastasis in neck. Bangladesh Journal of Otorhinolaryngology, 14(1), 15-22.

Cite This Article: Kishore Kumar Halder, Md. Shafiullah, Md. Saiful Islam, ABM Lutful Kabir, Banani Rani Mondal, Mahbubul Alam Choudhury, Md. Feroz Hossen (2022). Pattern of Metastases of Squamous Cell Carcinoma in Cervical Lymph Node. East African Scholars J Med Sci, 5(1), 1-4. 